\title{
Multiparameter characterisation of vertebral osteoporosis with 3-T MR
}

\section{Valutazione multiparametrica dell'osteoporosi vertebrale con RM a 3 Tesla}

\author{
E. Fanucci • G. Manenti • S. Masala • F. Laviani • G. Di Costanzo • A. Ludovici • V. Cozzolino \\ R. Floris • G. Simonetti
}

Università degli Studi di Roma “Tor Vergata”, Dipartimento di Diagnostica per Immagini e Radiologia Interventistica, Policlinico Universitario "Tor Vergata", Viale Oxford 81, I-00133 Roma, Italy

Correspondence to: E. Fanucci Tel.: +39-062-0902374, Fax: +39-062-0902404, e-mail: ezio.fanucci@libero.it

Received: 8 April 2006 / Accepted: 18 July 2006 / Published online: 19 March 2007

\begin{abstract}
Purpose. This study was undertaken to evaluate the diagnostic capabilities of 3-Tesla (T) magnetic resonance (MR) in vertebral osteoporosis.

Materials and methods. Thirty subjects (ten healthy controls, ten with osteoporosis but no fracture, ten with osteoporotic vertebral fractures) underwent MR of the lumbar spine. Turbo spin echo (TSE) T1-, T2- and T2- spectral selection attenuated inversion recovery (SPAIR) weighted imaging and spectroscopy for the selective evaluation of water and fat content were performed. The apparent diffusion coefficient (ADC) was calculated, and diffusion tensor imaging (DTI) was performed to create a map of the spatial arrangement of the tissue structures.

Results. Morphological imaging detected recent vertebral fractures. In osteoporotic patients, spectroscopic imaging demonstrated an increase in the saturated fats and a decrease in the $\mathrm{ADC}$, whereas the data provided by DTI demonstrated a bone structure with medium-degree anisotropy.

Discussion. Osteoporosis is characterised by trabecular thinning, with an increase in the intertrabecular spaces, which are filled with fats. The anisotropic study and the subsequent assessment of colour and vector maps can provide a noninvasive tool for assessing the risk of fracture due to osteoporosis.
\end{abstract}

Key words Osteoporosis • Vertebral collapse • 3-Tesla MR • Diffusion imaging • Tractography

\begin{abstract}
Riassunto
Obiettivo. Valutare la potenzialità diagnostica della RM 3 T nella valutazione della osteoporosi vertebrale.

Materiali e metodi. Trenta soggetti (10 volontari sani, 10 con osteoporosi senza fratture e 10 con fratture vertebrali osteoporotiche) sono stati sottoposti ad esame RM del rachide lombare. Sono state effettuate sequenze sagittali morfologiche TSE T2, TSE T1 e TSE T2 SPAIR pesate ed acquisizioni spettroscopiche per la valutazione selettiva del contenuto dell'acqua e dei lipidi; è stato poi calcolato il coefficiente apparente di diffusione $(A D C)$ e sono state eseguite sequenze del tensore di diffusione (DTI) per formare una mappa dell'orientamento spaziale delle strutture tissutali.

Risultati. L'imaging morfologico ha individuato le fratture vertebrali recenti. Nei pazienti osteoporotici l'imaging spettroscopico ha mostrato un aumento dei lipidi saturi ed una diminuzione dell'ADC mentre i dati forniti dal DTI hanno mostrato una struttura ossea con anisotropia di grado medio. Discussione. Nell'osteoporosi si assiste ad un assottigliamento e rarefazione della trabecolatura ossea, con aumento degli spazi intertrabecolari che vengono riempiti da lipidi. Il calcolo dell'anisotropia e la valutazione grafica colorimetrica e vettoriale forniscono un nuovo strumento non invasivo per valutare l'osteoporosi vertebrale.
\end{abstract}

Parole chiave Osteoporosi $\bullet$ Frattura vertebrale $\bullet$ RM a 3 Tesla $\bullet$ Immagini in diffusione $\bullet$ Trattografia

\section{Introduction}

Bone mineral density (BMD) is perhaps the best index available for assessing the risk of osteoporotic fracture. Lindsay et al. [1] reported that each reduction of one standard deviation of BMD corresponds to a $60 \%$ increase in the risk of vertebral fractures. These figures have been confirmed by other clinical studies that showed that the risk of a new fracture within the first year of a previous compression fracture increases from 5 to 25 times [2]. Magnetic resonance (MR)

\section{Introduzione}

La densità minerale ossea è forse il miglior indice attualmente disponibile per la valutazione del rischio di fratture osteoporotiche. Lindsay et al. hanno riportato che ad ogni riduzione di una deviazione standard della BMD corrisponde un aumento del $60 \%$ del rischio di frattura vertebrale [1]. Tali dati sono stati inoltre confermati da ulteriori studi clinici in cui si è dimostrato che il rischio di una nuova frattura vertebrale entro il primo anno da una precedente frattura 
is yet to find a role in the quantification of the risk of fracture, with its use currently being limited to assessing fractures already present. The aim of this study was therefore to assess the possibility of a multiparameter characterisation, and not only imaging, of vertebral osteoporosis using 3-Tesla (T) MR.

\section{Materials and methods}

In our study, 30 subjects underwent an MR examination of the lumbar spine. These included ten healthy volunteers (three men and seven women) aged between 31 and 68 years without metabolic bone diseases (in particular, osteoporosis - T-score $\leq-1$ ) or neoplastic disease in any district; ten female patients aged between 55 and 78 years with osteoporosis (T-score $\leq-2.5)$ but without vertebral fractures identifiable with conventional radiology; and ten female patients aged between 60 and 75 years with a single osteoporotic lumbar vertebral fracture identified in a prior radiographic examination of the spine and with dual X-ray absorptiometry (DEXA) positive for osteoporosis, a negative history of recent traumatic events and the absence of other metabolic and neoplastic bone diseases. All patients were informed of the experimental nature of the examination, and they all signed informed consent before undergoing the study.

The morphological, metabolic and functional images were acquired with a high-field device (3.0 T) (Philips Intera Achieva, Best, Netherlands), with a maximum gradient strength and slew rate set to $80 \mathrm{mT} / \mathrm{m}$ and $200 \mathrm{mT} / \mathrm{m} / \mathrm{ms}$, respectively, using a body coil for signal transmission and a synergy spine phased-array coil for signal reception.

The study of the lumbar spine was performed with the following sequences:

- T2-weighted turbo spin echo (TSE) in the sagittal plane including in the acquisition volume the entire lumbar-sacral tract (TR shortest, TE $120 \mathrm{~ms}$, slice thickness $4 \mathrm{~mm}$ with an interval between the sections of 0.4 $\mathrm{mm}$, FOV $300 \mathrm{~mm}$ and a $512 \times 512$ matrix)

- T1-weighted TSE in the sagittal plane (TR shortest, TE $7.2 \mathrm{~ms}$, slice thickness $4 \mathrm{~mm}$ with an interval between sections of $0.4 \mathrm{~mm}$, FOV $300 \mathrm{~mm}$ and a 512×512 matrix)

- T2-weighted TSE with selective fat suppression [spectral selection attenuated inversion recovery (SPAIR)] in the sagittal plane aimed at assessing the presence of bone marrow oedema, an index of recent fracture in collapsed vertebral bodies and of algodystrophic changes in response to biomechanical stress in noncollapsed vertebral bodies.

On the basis of the T2-weighted images, especially the SPAIR images, two independent observers identified the vertebral bodies with altered signal intensity, which were selected for placement of the spectroscopy acquisition volume. Spectroscopic acquisition in the healthy subjects was optimised in the mid-lumbar vertebral bodies in accordance with the literature. Spectroscopic acquisition was used to assess water and fats. The volume of interest (VOI) for spectroscopic analysis was chosen on the basis of the T2 and T2- compressiva aumenta dalle 5 alle 25 volte [2]. La RM non ha ancora trovato un ruolo nella quantificazione del rischio di frattura, attestandosi per ora nella valutazione del crollo già avvenuto. Lo scopo del nostro lavoro è pertanto quello di valutare la possibilità di una caratterizzazione multiparametrica, e non solo di imaging, dell'osteoporosi vertebrale mediante RM a 3 Tesla.

\section{Materiali e metodi}

Nel nostro studio sono stati sottoposti ad esame RM del rachide lombare 30 soggetti: 10 volontari sani (3 maschi e 7 femmine), di età compresa tra 31 e 68 anni, esenti da patologie metaboliche dell'osso (in particolare osteoporosi, T-score $\leq-1)$ e da patologie neoplastiche di qualsiasi distretto; $10 \mathrm{pa}$ zienti di sesso femminile di età compresa tra 55 e 78 anni con osteoporosi (T-score $\leq-2,5)$ ma esenti da fratture vertebrali evidenziabili con esami di radiologia tradizionale; 10 pazienti di sesso femminile di età compresa tra 60 e 75 anni con frattura vertebrale lombare singola a genesi osteoporotica, evidenziata ad un precedente esame radiografico del rachide e DEXA positiva per osteoporosi, anamnesi negativa per eventi traumatici recenti, in assenza di altre patologie metaboliche e neoplastiche dell'osso. Tutti i pazienti sono stati informati sul carattere sperimentale dell'esame ed hanno firmato un consenso prima di essere sottoposti all'indagine.

Le immagini morfologiche, così come quelle metaboliche e funzionali, sono state acquisite con un'apparecchiatura ad alto campo (3,0 Tesla) (Philips Intera Achieva, Best, Netherlands) equipaggiata con gradienti di ampiezza massima e tempo di salita di $80 \mathrm{mT} / \mathrm{m}$ e $200 \mathrm{mT} / \mathrm{m} / \mathrm{ms}$ rispettivamente, utilizzando la bobina del corpo per la trasmissione degli impulsi di eccitazione e una bobina "sinergy spine phased-array" per la ricezione del segnale.

Lo studio del rachide lombare è stato eseguito mediante le seguenti sequenze:

- TSE T2 pesata sul piano sagittale includendo nel volume d'acquisizione l'intero tratto lombo-sacrale (TR shortest, TE $120 \mathrm{~ms}$, spessore di sezione $4 \mathrm{~mm}$ con intervallo tra le sezioni di 0,4 mm, FOV di $300 \mathrm{~mm}$ e una matrice di $512 \times 512$ );

- TSE T1 pesata sul piano sagittale (TR shortest, TE 7,2 ms, spessore di sezione $4 \mathrm{~mm}$ con intervallo tra le sezioni di 0,4 mm, FOV di $300 \mathrm{~mm}$, matrice di 512×512);

- TSE T2 pesata con soppressione selettiva del segnale del tessuto adiposo (SPAIR) sul piano sagittale, al fine di valutare l'eventuale presenza di edema intraspongioso, indice di frattura recente per i somi vertebrali crollati e di trasformazione da sostituzione algodistrofica per adattamenti intrinseci da sofferenza biomeccanica per quelli non crollati.

Sulla base delle immagini $T 2$ pesate, soprattutto SPAIR, sono state individuate da due osservatori indipendenti le vertebre con alterata intensità di segnale, selezionate per il successivo posizionamento del volume di acquisizione spettroscopica. Nei soggetti sani l'acquisizione spettroscopica è stata ottimizzata sui somi medio-lombari in accordo con 
SPAIR images in the sagittal plane. Acquisition was performed with a point-resolved spectroscopy (PRESS) sequence (double spin-echo point resolved spatially localised spectroscopic sequence) with the two-dimensional (2D) technique and echo time (40 ms) optimised for quantitative assessment of water and fats, with single voxel analysis. Field homogeneity was adjusted through an automatic procedure of localised three-dimensional (3D) shimming. The following acquisition parameters were used: TR 2,000 ms, TE $40 \mathrm{~ms}$, spectral width $2.00 \mathrm{~Hz}$, matrix $512 \times 512$, nominal voxel resolution $25 \mathrm{~mm} \times 25 \mathrm{~mm} \times 15 \mathrm{~mm}$. Acquisition time of the spectroscopy sequence was on average 2 min for each vertebral body examined.

We performed three acquisitions with voxels positioned at the level of L2, L3 and L4 in healthy patients and osteoporotic patients without vertebral collapse. In patients with a fractured vertebra, we performed three acquisitions with voxels positioned in the pathological vertebra, the overlying vertebra and the underlying vertebra, respectively. The spectra obtained were processed with Fourier transformation. The fat content was expressed as the percentage of the fat signal intensity in respect to total signal intensity (fat fraction: FF). The FF values obtained were compared using Student's $t$ test. A $p$ value lower than 0.05 was considered statistically significant.

Diffusion-weighted (DW) images were acquired with single-shot spin-echo echoplanar imaging (SE-EPI) in the sagittal plane, with a duration of $35 \mathrm{~s}$ (TR 3,500 ms, TE $62 \mathrm{~ms}$, FOV $200 \mathrm{~mm}$, flip angle $90^{\circ}$, matrix $256 \times 256$, b-value set to 0 and $400 \mathrm{~mm}^{2} / \mathrm{s}$, three sections $5-\mathrm{mm}$ thick with a $1-\mathrm{mm}$ gap). The apparent diffusion coefficient (ADC) was calculated by positioning regions of interest (ROIs) in the vertebral bodies examined with spectroscopy of varying size so as to almost entirely cover the body. The mean ADC values of each group of patients was calculated and compared with those of the other groups using Student's $t$ test. A $p$ value below 0.05 was considered statistically significant. The diffusion tensor images were acquired with the same technique and using the same acquisition parameters, with sampling of the random motion of free water in 32 directions in space (directional resolution HIGH). Acquisition time was about 2 min.

The fractional anisotropy (FA) was then calculated, a parameter that describes the degree of variation of diffusion in space (a value between $0=$ highly isotropic with the direction of water molecule diffusion being highly random, and $1=$ anisotropic, with the preferential motion of water molecules being highly directional) and the main direction of water molecule diffusion. This parameter, which can be derived from the tensor, is linked with the possibility of mapping the spatial orientation of tissue structures; the technique is also known as fibre tracking or tractography [3].

Images obtained with the diffusion tensor imaging (DTI) sequence were first analysed on the acquisition console to identify the presence of motion artefacts and image distortions related to the presence of eddy currents. Significant misalignments were found in three patients due to motion and distortions related to eddy currents, and these images quanto riportato in letteratura. Con l'acquisizione spettroscopica sono stati valutati l'acqua ed i lipidi. Il volume di interesse sottoposto ad analisi spettroscopica (VOI) è stato selezionato sulla base delle immagini T2 e T2-SPAIR sul piano sagittale. L'acquisizione è stata effettuata con sequenza PRESS (double spin-echo Point-REsolved Spatially localized Spectroscopic sequence) con tecnica bidimensionale (2DSI) e tempo di Eco $(40 \mathrm{~ms})$ ottimizzato per la valutazione quantitativa dell'acqua e dei lipidi, con analisi single voxel. L'omogeneizzazione del campo magnetico è stata effettuata con una procedura automatica di "shimming" tridimensionale localizzato. I parametri di acquisizione utilizzati sono stati i seguenti: TR $2000 \mathrm{~ms}$, TE $40 \mathrm{~ms}$, ampiezza spettrale $2000 \mathrm{~Hz}$, matrice di $512 \times 512$, risoluzione nominale del voxel di $25 \mathrm{~mm} \times 25 \mathrm{~mm} \times 15 \mathrm{~mm}$. Il tempo di acquisizione della sequenza spettroscopica è stato in media di 2 minuti per ogni corpo vertebrale in esame.

Nei pazienti sani ed in quelli osteoporotici senza crollo vertebrale sono state effettuate tre acquisizioni con voxel posizionati a livello di L2, L3 ed L4. Nei pazienti con vertebra fratturata sono state effettuate tre acquisizioni con voxel posizionati rispettivamente a livello della vertebra patologica e delle vertebre immediatamente sopra e sottostante. Gli spettri ottenuti sono stati elaborati mediante la trasformata di Fourier. Il contenuto di lipidi è stato espresso in percentuale come intensità di segnale relativa dei lipidi rispetto all'intensità di segnale totale (fat fraction: FF). I valori di FF ottenuti sono stati confrontati tra loro mediante un test $t$ di Student. Un valore di p inferiore a 0,05 è stato considerato significativo.

Le immagini pesate in diffusione sono state ottenute con tecnica a singolo impulso (single-shot) Spin Echo Ecoplanare (SE EPI) sul piano sagittale, della durata di circa $35 \mathrm{~s}$ (TR $3500 \mathrm{~ms}$, TE $62 \mathrm{~ms}$, FOV $200 \mathrm{~mm}$, flip angle 90 $0^{\circ}$ matrice $256 \times 256$, valore di fattore b pari a 0 e $400 \mathrm{~mm}^{2} / \mathrm{s}, 3$ sezioni di $5 \mathrm{~mm}$ di spessore con gap di $1 \mathrm{~mm}$ ). Il coefficiente di diffusione apparente $(A D C)$ è stato calcolato posizionando delle ROIs nel contesto dei corpi vertebrali già sede dell'analisi spettroscopica, di dimensioni variabili in modo da comprendere quasi completamente l'intero soma. Il confronto tra $i$ valori medi di ADC di ogni gruppo di pazienti è stato calcolato e comparato con quello degli altri gruppi usando un test $t$ di Student. Un valore di p inferiore a 0,05 è stato considerato statisticamente significativo. Le immagini del tensore di diffusione sono state acquisite con la medesima tecnica, utilizzando $i$ medesimi parametri di acquisizione, campionando i movimenti casuali dell'acqua libera su 32 direzioni dello spazio (directional resolution HIGH). La durata dell'acquisizione è stata di circa 2 minuti.

È stato quindi calcolato il grado di anisotropia (fractional anisotropy: FA), che descrive la entità di variazione della diffusione nello spazio (valore compreso tra $0=$ altamente isotropico con direzione di diffusione delle molecole di acqua assolutamente casuale, e $1=$ anisotropico, con movimento preferenziale delle molecole di acqua altamente direzionato), e la direzione principale di diffusione delle molecole di acqua. Quest'ultimo parametro, che può essere derivato dal tensore, è correlato con la possibilità di eseguire un 
were discarded. Data were then processed with a dedicated software package (PRIDE V4 - Fiber Tracking 4.1, IDL, Research Systems, Boulder, CO, USA).

A single rectangular ROI was positioned on the images acquired with the b-value set to 0 in the same vertebral bodies assessed with spectroscopy imaging (using the criteria for analysis of the morphological images mentioned above). All ROIs were then automatically transposed onto the corresponding image on the grey-scale maps of mean diffusivity (MD) and FA generated by the software package. MD values, expressed as a value of ADC, and FA values were then calculated as the mean of the values derived from each pixel of the ROI examined. The anisotropy was also visualised by the generation of a 24-bit RGB colour map, which depicted the relative size of each vector value. Extremely anisotropic structures are shown with a colour varying from black to deep blue, areas with intermediate anisotropy are shown with a colour varying from orange to purple and isotropic structures are shown in grey scale. The structural anatomy of the vertebral body was assessed with the representation of the preferential direction of the fibres on a directionally encoded colour (DEC) map [4].

This information was obtained pixel per pixel on the basis of the vector corresponding to the highest value [5], in which red indicates the fibres that run in the left-right direction, green the fibres that run in the anterior-posterior direction, and blue the fibres that run in the superior-inferior direction. Tensor data underwent additional processing using the "continuous tracking" technique [6]. To this end, an ROI was manually traced on the images acquired with a b-value set to 0 along the internal margin of the vertebral body cortex. The reconstruction software automatically extracted the fibres, linking in each voxel the main vector with those of the adjacent voxels. This procedure evinced the progressive definition of the preferential diffusivity trajectory, which probably corresponds to the direction of the trabeculae of the cancellous bone of the vertebral body. The fibres represented in this way were superimposed on the non-DW echoplanar images $(b=0)$ and codified by assigning them the colour corresponding to the preferential direction in accordance with the model outlined above. The overall time required to process the diffusion tensor data, including the data transfer from the acquisition workstation to the postprocessing workstation and the tractographic analysis, was on average $20 \mathrm{~min}$. FA values and colour and vector maps obtained were compared.

\section{Results}

\section{Morphological imaging}

The T2-weighted images proved to be highly diagnostic, particularly with SPAIR, which, on the basis of areas of signal hyperintensity within fractured vertebral bodies, enabled recent fractures (generally having occurred within a period of less than 6 months) to be distinguished from stabilised fractures (Fig. 1). "mapping" dell'orientamento spaziale delle strutture tissutali ; la tecnica è conosciuta anche come "fiber tracking" o trattografia [3].

Le immagini ottenute con la sequenza del tensore di diffusione (DTI) sono state dapprima analizzate sulla consolle di acquisizione al fine di individuare eventuali artefatti legati al movimento e distorsioni delle immagini correlate alla presenza di correnti indotte (Eddy currents). Tre pazienti hanno presentato significativi disallineamenti legati al movimento e distorsioni legate alle correnti indotte e sono stati scartati. I dati sono stati poi rielaborati con software dedicato (PRIDE V4, Fiber Tracking 4.1, IDL, Research Systems, Boulder, $C O)$ all'analisi del DTI e al "fiber tracking".

Una singola ROI rettangolare è stata posizionata sulle immagini acquisite con b factor uguale a 0 in corrispondenza degli stessi somi valutati con imaging spettroscopico (utilizzando i criteri precedentemente visti per l'analisi delle immagini morfologiche). Tutte le ROI sono state poi trasposte automaticamente sull'immagine corrispondente sulle mappe in scala di grigi di diffusività media $(M D)$ e di anisotropia frazionaria (FA) generate dal software di analisi. I valori di $M D$, espressi come valore di ADC, e di FA sono stati poi calcolati come media dei valori derivati da ciascun pixel della ROI esaminata. L'anisotropia è stata anche visualizzata mediante la generazione di una mappa colorimetrica a 24-bit $R G B$ che rifletteva la grandezza relativa di ciascun valore vettoriale. Strutture estremamente anisotropiche appaiono di un colore che varia dal nero al blu; aree con anisotropia intermedia sono rappresentate con un colore che va dall'arancione al viola; strutture isotropiche sono rappresentate in scala di grigio. L'anatomia strutturale del corpo vertebrale è stata valutata, rappresentando su di una mappa a colori (Directionally-Encoded Color, DEC) la direzione preferenziale delle fibre [4].

Questa informazione è stata ottenuta pixel per pixel sulla base del vettore corrispondente al valore più grande [5] nel quale il colore rosso indica le fibre che decorrono lungo la direzione destra-sinistra, il verde quelle lungo la direzione anteriore-posteriore ed il blu quelle lungo la direzione superiore-inferiore. I dati del tensore sono stati ulteriormente elaborati con analisi trattografica secondo il metodo del "Continuous Tracking" [6]. A tal fine è stata tracciata manualmente sulle immagini acquisite con $b$ value $=0$ una ROI lungo il margine interno della corticale ossea del corpo vertebrale. Il software di ricostruzione ha poi effettuato automaticamente l'estrazione delle fibre concatenando, in ciascun voxel, il vettore principale con quelli dei voxel vicini. Tale elaborazione è risultata in una progressiva definizione della traiettoria della diffusività preferenziale che corrisponde verosimilmente alla direzione delle trabecole dell'osso spongioso del corpo vertebrale. Le fibre così rappresentate sono state sovrapposte alle immagini ecoplanari non pesate in diffusione ( $b$ value $=0)$ e codificate assegnando loro il colore corrispondente alla direzione preferenziale secondo lo schema visto precedentemente. Il tempo complessivo necessario all'elaborazione dei dati del tensore di diffusione, compreso il trasferimento dei dati dalla stazione di acquisizione a quella di elaborazione e l'analisi trattografica, è stato in media di circa 20 minuti. I valo- 


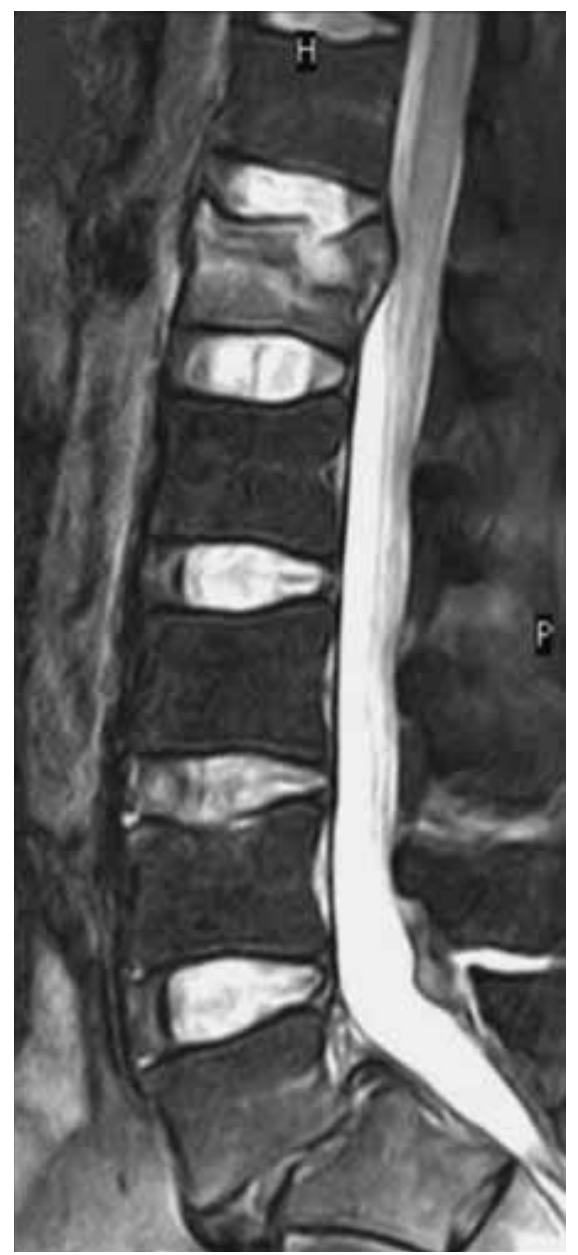

Fig. 1 A 64-year-old osteoporotic woman. Series of images acquired with the spectral selection attenuated inversion recovery (SPAIR) technique to suppress the fat tissue signal. The L1 cancellous bone appearing more hyperintense is a sign of bone marrow oedema caused by recent fracture.

Fig. 1 Donna osteoporotica di 64 anni. Sequenza di immagini acquisite con tecnica SPAIR per la soppressione del segnale del tessuto adiposo. Con questa sequenza è molto meglio evidente l'iperintensità della spongiosa ossea di L1, segno di edema intraspongioso e quindi di frattura recente.

\section{Spectroscopy}

We acquired 104 spectra with the single voxel technique, excluding 12 spectra from the study that were not assessable due to motion artefacts and excessive background noise. The remaining spectra were analysed and compared. Qualitative assessment revealed a spectral resolution high enough to separate water resonance $(4.7 \mathrm{ppm})$ from fat resonance $(1.3$ $\mathrm{ppm})$. The water peak in healthy subjects was significantly higher than the fat peak, with an inverse progression as patient age increased and T-score decreased (inversion of the water/fat ratio). The spectral resolution of the sequence also revealed a notably higher increase in saturated fatty acids (especially methylene: $1.3 \mathrm{ppm}$ ) than unsaturated fatty acids (olefinic protons: $5.25 \mathrm{ppm}$ ) [7] in osteoporotic patients compared with healthy patients. The mean FF value measured in the vertebral bodies of the healthy volunteers and obtained from the three measurements was $34 \% \pm 10.6 \%$ ri di FA, le mappe ed i grafici ottenuti sono stati confrontati tra loro.

\section{Risultati}

Imaging morfologico

Sono risultate altamente diagnostiche le sequenze T2 pesate, soprattutto con tecnica di soppressione del tessuto adiposo (SPAIR), le quali hanno permesso di distinguere, in base alla presenza di aree di iperintensità di segnale all'interno dei corpi vertebrali fratturati, tra frattura recente (generalmente intervenuta in un tempo inferiore a 6 mesi) e frattura stabilizzata (Fig. 1).

Spettroscopia

Sono stati acquisiti 104 spettri con la tecnica single voxel. Dodici spettri sono stati esclusi dallo studio perché non interpretabili, a causa di artefatti da movimento e da eccessivo rumore di fondo. I restanti spettri sono stati analizzati e confrontati tra loro. La valutazione qualitativa degli spettri ha evidenziato una risoluzione spettrale sufficiente a separare la risonanza dell'acqua (4,7 ppm) da quella dei lipidi (1,3 ppm). Il picco dell'acqua nei soggetti sani è risultato significativamente più elevato di quello dei lipidi, con andamento inverso man mano che l'età dei pazienti aumentava ed $i$ valori di T-score diminuivano (inversione del rapporto acquallipidi). La risoluzione spettrale della sequenza ha inoltre permesso di evidenziare un aumento degli acidi grassi saturi (in particolare il metilene: 1,3 ppm) nettamente superiore rispetto agli acidi grassi insaturi (protoni oleofinici: 5,35 ppm) [7] nei pazienti osteoporotici rispetto a quelli sani. Il valore medio della frazione lipidica $(F F)$ misurato nei corpi vertebrali dei volontari sani ottenuto dalle tre misurazioni è risultato pari a $34 \% \pm 10,6 \%$ (range compreso tra $29 \% \pm 9,6 \%$ e $56,3 \% \pm 11,2 \%$ ), con incremento medio anпио di circa il $2 \%$ e valori leggermente più alti nei maschi. I soggetti sani in età pre-menopausa hanno inoltre presentato un contenuto medio di lipidi nel midollo osseo significativamente più basso rispetto ai soggetti sani di età superiore a 50 anni $(p<0,001)$ (Figg. 2, 3). Nel gruppo dei pazienti osteoporotici la FF media calcolata è stata $65,5 \% \pm 10 \%$ (range compreso tra 55,2\% $\pm 9,8 \%$ e $74,5 \% \pm 11,2 \%$ ). Non sono state rilevate differenze statisticamente significative tra il gruppo di pazienti osteoporotici che non presentavano frattura vertebrale ed il gruppo di pazienti che presentavano frattura vertebrale $(p<0,827)$ (Fig. 4$)$, E stata invece rilevata una differenza molto significativa tra il valore medio di FF nei pazienti sani e quello dei pazienti osteoporotici $(p<0,001)$ con notevole aumento della $F F$ in questi ultimi (Fig. 5). L'analisi spettroscopica dei corpi vertebrali che presentavano una netta iperintensità di segnale nelle sequenze $T 2$ pesate in pazienti osteoporotiche ha tuttavia mostrato un rapporto acqua/lipidi apparentemente conservato. Tale dato è da mettere in relazione verosimilmente alla presenza di edema intraspongioso all'interno del corpo vertebrale in esame. 


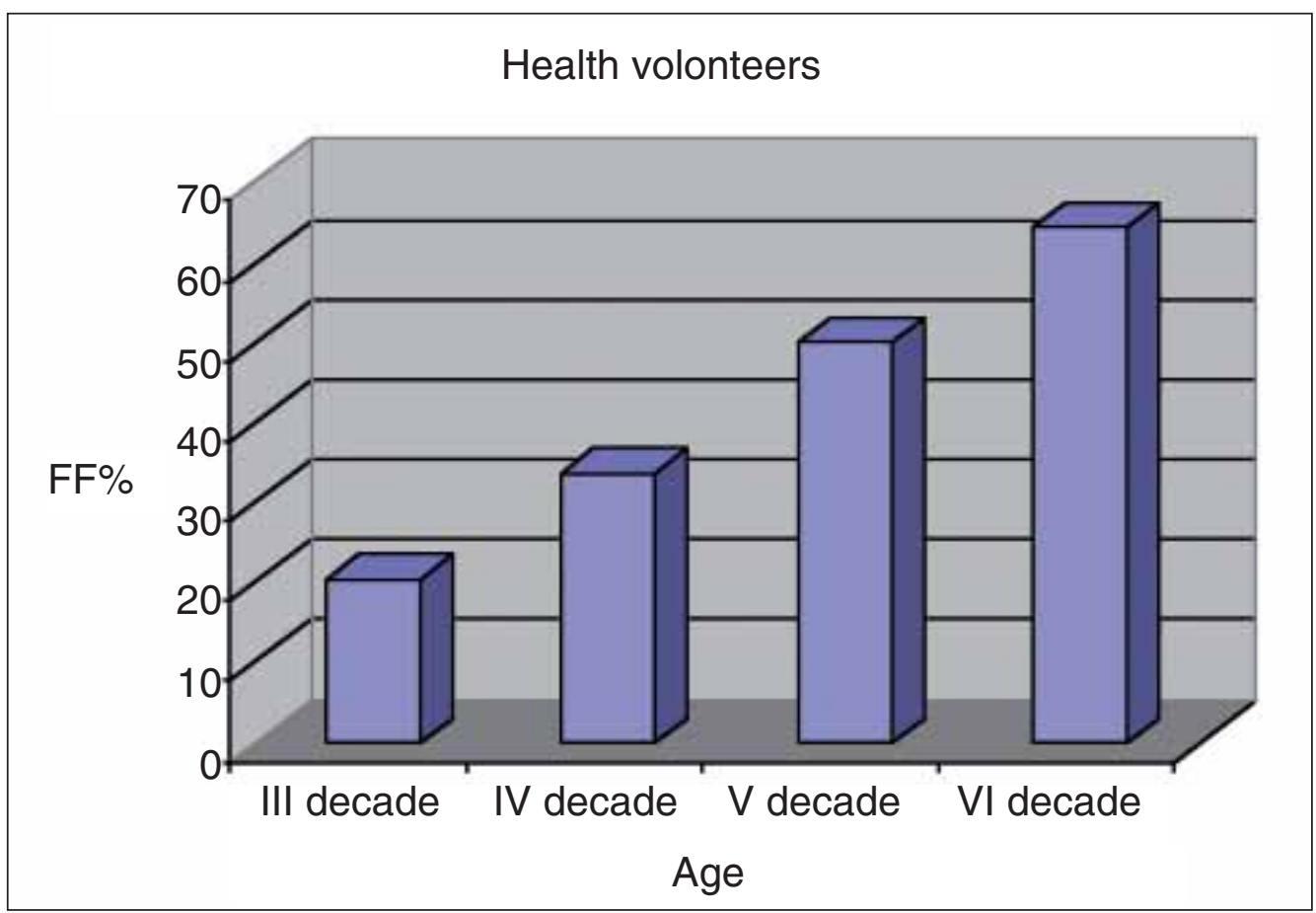

Fig. 2 Relationship between fat fraction (FF) and age. Patients are grouped by age in 10-year intervals. There is a linear increase in FF value with age.

Fig. 2 Relazione tra valori di Fat Fraction $(F F)$ espressi in percentuale ed età. I soggetti sono raggruppati per decadi. Esiste un incremento lineare dei valori di FF\% con l'età.

(range $29 \% \pm 9.6 \%$ to $56.3 \% \pm 11.2 \%$ ), with a mean annual increase of about $2 \%$ and values slightly higher in males. Healthy subjects in the premenopausal age range also had a mean fat content in the bone marrow significantly lower than healthy subjects older than 50 years $(p<0.001)$ (Figs. 2, 3). The mean FF value in osteoporotic patients was $65.5 \% \pm 10 \%$ (range $55.2 \% \pm 9.8 \%$ to $74.5 \% \pm 11.2 \%$ ). No statistically significant differences were found between osteoporotic patients without vertebral fractures and patients with vertebral fractures $(p<0.827)$ (Fig. 4). A highly significant difference, however, was found between the FF value in healthy patients and osteoporotic patients $(p<0.001)$, with a significant increase in FF in the latter group (Fig. 5). Spectroscopic analysis of vertebral bodies with a clearly hyperintense signal in the T2-weighted sequences in osteoporotic patients, however, revealed an apparently retained water/fat ratio. This finding is likely due to the presence of bone marrow oedema within the vertebral body under study.

Table 1 summarises the mean FF values correlated with the $\mathrm{T}$ score and the age of the patient undergoing the spectroscopic examination. In some cases of osteoporotic patients, there was an overlapping of FF values with those of postmenopausal patients with a normal $\mathrm{T}$ score.

Proton-diffusion and tensor-diffusion imaging

We positioned 104 ROIs in as many vertebral bodies and calculated the ADC and FA values. The images obtained with DTI were used to process the colour and vector maps. Four uncooperative patients were excluded from the study.
Nella Tabella 1 sono riassunti $i$ valori medi di FF correlati al T-score ed all'età dei pazienti sottoposti ad esame spettroscopico. In alcuni casi di pazienti osteoporotici si è verificata una sovrapposizione dei valori di FF con quelli di pazienti con normale T-score in età postmenopausale.

Diffusione protonica e tensore di diffusione

Sono state posizionate 104 ROIs in altrettanti corpi vertebrali e calcolati i relativi valori di coefficiente di diffusione apparente $(A D C)$ e di anisotropia frazionata (FA). Dalle immagini ottenute con la tecnica del tensore di diffusione sono successivamente state elaborate le relative mappe colorimetriche ed i grafici vettoriali. Quattro pazienti sono stati esclusi dallo studio perchè non collaboranti. I restanti dati ottenuti sono stati analizzati e confrontati tra loro. Nel gruppo di soggetti sani il valore medio dell'ADC ottenuto dalla misurazione nei tre corpi vertebrali in esame (L2, L3 ed L4) è risultato di $0,48 \pm 0,05 \times 10^{-3} \mathrm{~mm}^{2} / \mathrm{s}$ (range compreso tra $0,44 \pm 0,08 \times 10^{-3} \mathrm{~mm}^{2} / \mathrm{s}$ e $0,52 \pm 0,07 \times 10^{-3} \mathrm{~mm}^{2} / \mathrm{s}$ ). I valori più bassi sono stati riscontrati nei soggetti in età postmenopausale $(p<0,001)$ (Fig. 6). La valutazione quantitativa del grado di anisotropia ha condotto a risultati in parte sovrapponibili a quelli relativi al calcolo dell'ADC. Il calcolo della $F A$ in tale gruppo ha infatti mostrato un valore medio di 0,29 (valore tendente all'isotropia) con range tra 0,23 e 0,36 . I valori più bassi sono stati riscontrati nei soggetti in età pre-menopausa $(p<0,005)$. Le mappe colorimetriche relative al grado di anisotropia hanno dimostrato in tutti i pazienti di questo gruppo una gradazione di colori relativa 


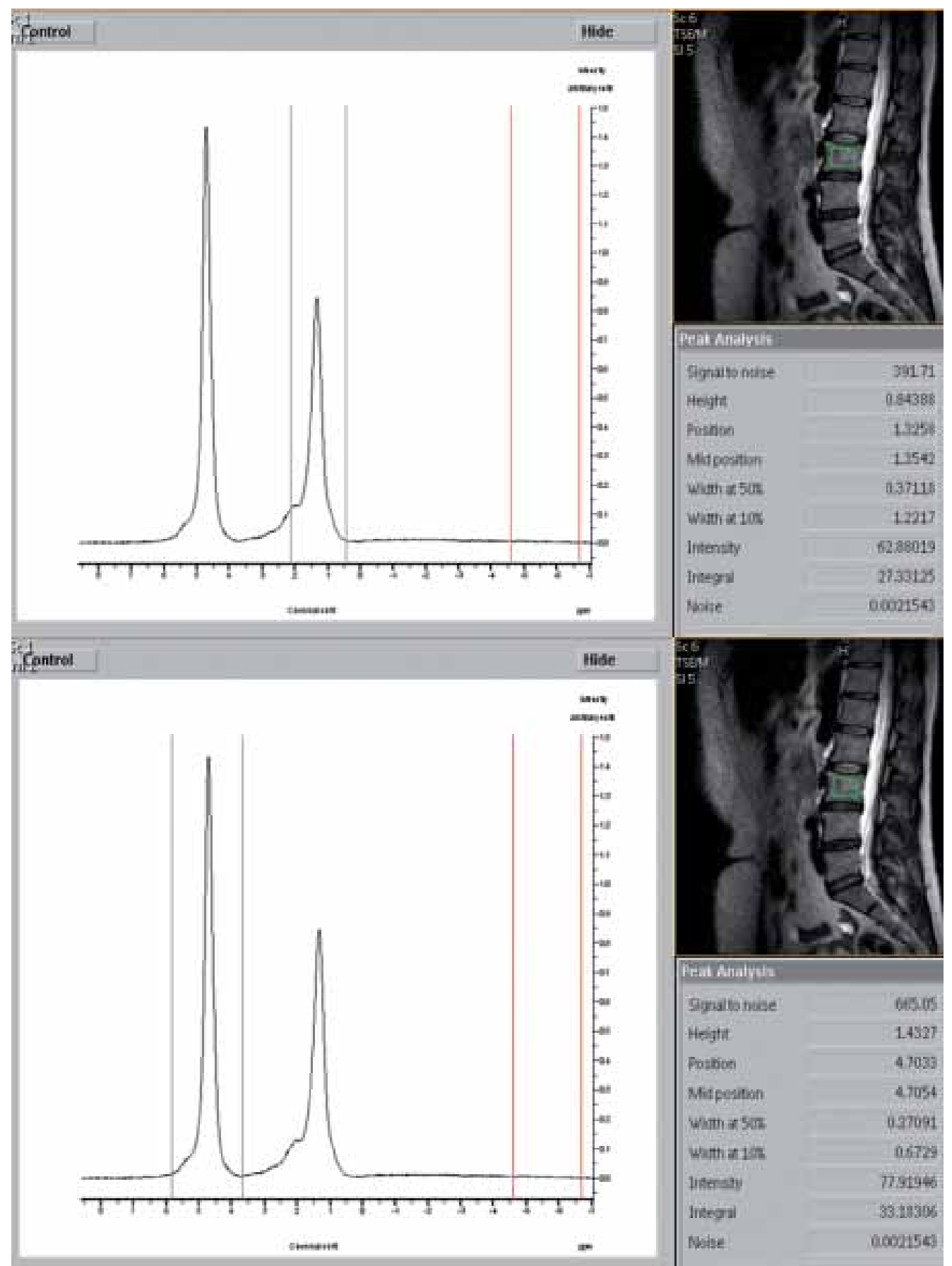

Fig. 3 Spectroscopic analysis with evaluation of fat (1.3 ppm) and water component in a 39-year-old healthy woman showing a normal water/fat ratio [fat fraction (FF) $40.5 \%]$.

Fig. 3 Analisi spettroscopica con relativo calcolo della componente lipidica (1,3 ppm) e dell'acqua in un volontario sano di sesso femminile di 39 anni che mostra normale rapporto acquallipidi (FF $40,5 \%)$ 


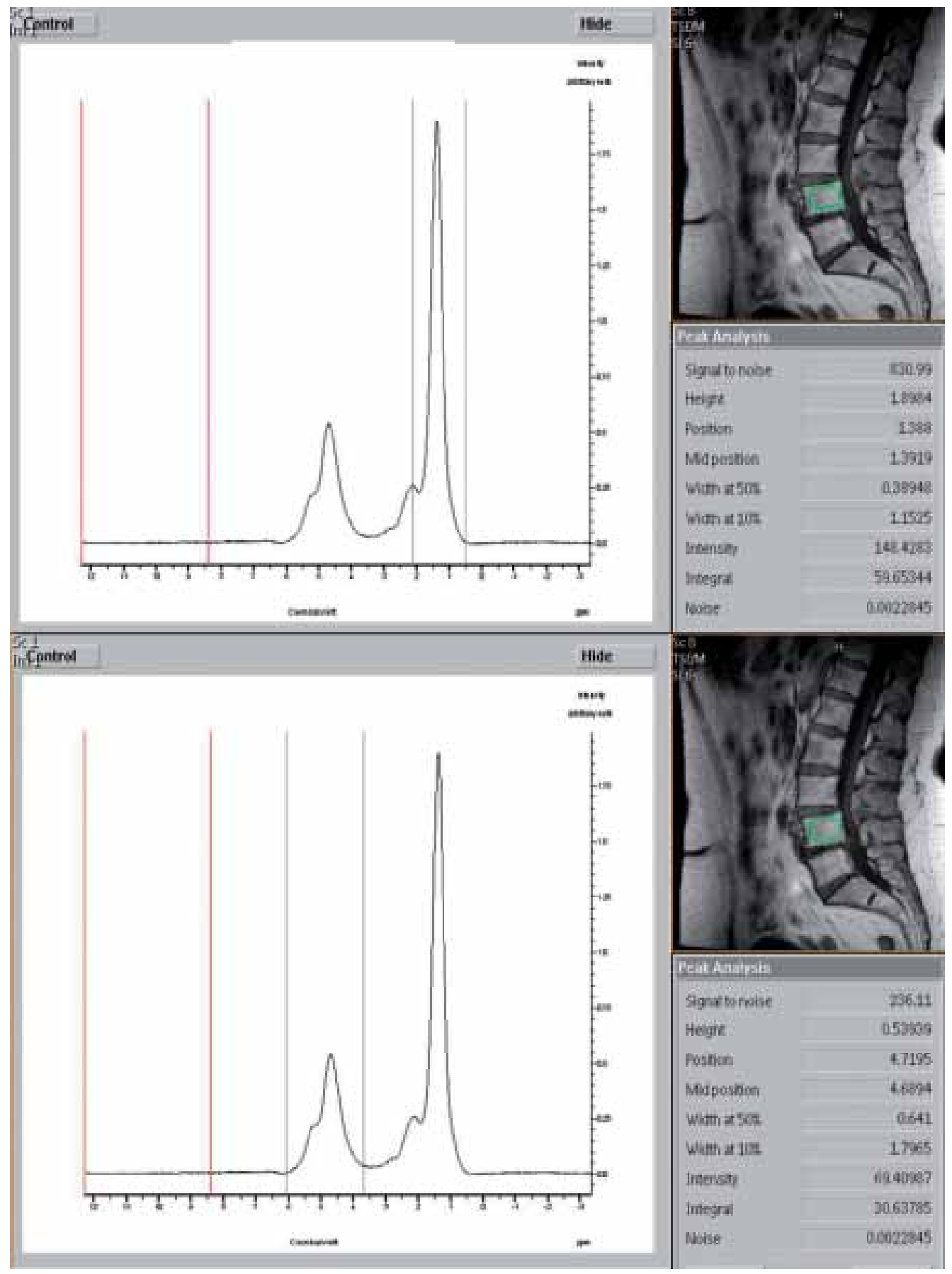

Fig. 4 Spectroscopic analysis with evaluation of the water and main fat component in a 69-year-old osteoporotic female patient (T score -2.5) without vertebral fractures showing an inversion of the water/fat ratio [fat fraction (FF) $72.5 \%$ ].

Fig. 4 Analisi spettroscopica con relativo calcolo della componente lipidica principale e dell'acqua in un soggetto osteoporotico (T-score -2,5) senza frattura vertebrale, di sesso femminile di 69 anni, che mostra evidente inversione del rapporto acqua/lipidi (FF 72,5\%). 
Table 1 Spectroscopy findings

\begin{tabular}{llll}
\hline Subject group & Mean age (years) & T score & Fat fraction (FF) $(\%)$ \\
\hline Healthy younger than 50 years & 40 & ND & $28.6 \pm 6.2$ \\
Healthy older than 50 years & 61 & $-0.3 \pm 0.7$ & $57.3 \pm 9.6$ \\
Osteoporotic & 67 & $-3 \pm 0.5$ & $65.5 \pm 8.5$ \\
\hline
\end{tabular}

Data expressed in terms of mean and standard deviation

$N D$, no data

Tabella 1 Risultati della valutazione spettroscopica

\begin{tabular}{llll}
\hline Gruppi di soggetti & Età media, anni & T-score & $F F(\%)$ \\
\hline Sani di età inferiore a 50 anni & 40 & $N D$ & $28,6 \pm 6,2$ \\
Sani di età superiore a 50 ann & 61 & $-0,3 \pm 0,7$ & $57,3 \pm 9,6$ \\
Osteoporotici & 67 & $-3 \pm 0,5$ & $65,5 \pm 8,5$ \\
\hline
\end{tabular}

Dati espressi in termini di media e deviazione standard ND, no data

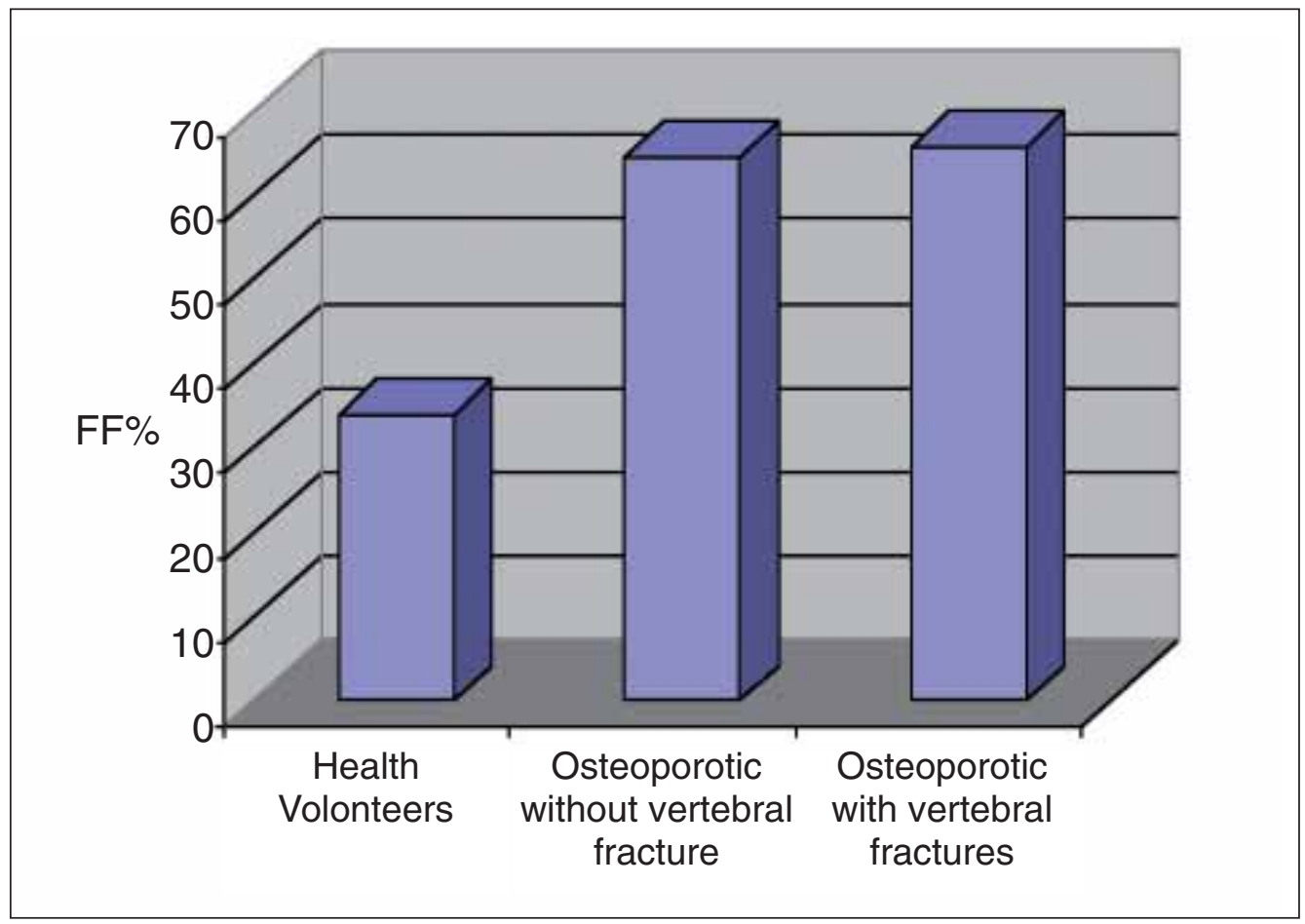

Fig. 5 Comparison between fat-fraction (FF) values in healthy and osteoporotic patients with and without vertebral fracture. There is a significant difference between FF values in nonosteoporotic and osteoporotic subjects. This is not dependent on the presence of vertebral fracture.

Fig. 5 Confronto tra $i$ valori medi di FF nei soggetti sani ed in quelli osteoporotici con e senza frattura vertebrale. Esiste una differenza significativa tra $i$ valore di FF dei soggetti non osteporotici e quello dei soggetti osteoporotici indipendentemente dalla presenza di frattura vertebrale.

The remaining data obtained were analysed and compared. In the group of healthy volunteers, the mean ADC value obtained from measurements in the three vertebral bodies (L2, L3 and L4) was $0.48 \pm 0.05 \times 10^{-3} \mathrm{~mm}^{2} / \mathrm{s}$ (range between $0.44 \pm 0.08 \times 10^{-3} \mathrm{~mm}^{2} / \mathrm{s}$ and $\left.0.52 \pm 0.07 \times 10^{-3} \mathrm{~mm}^{2} / \mathrm{s}\right)$. The lower values were found in postmenopausal patients $(p<0.001)$ (Fig. 6). Quantitative assessment of the degree of all'intero corpo vertebrale compatibile con una struttura caratterizzata da un'anisotropia di basso grado (Fig. 7).

Il valore medio dell'ADC del gruppo di pazienti affetti da osteoporosi senza frattura vertebrale è risultato di $0,42 \pm 0,09 \times 10^{-3} \mathrm{~mm}^{2} / \mathrm{s}$ (range compreso tra $0,44 \pm 0,09 \times 10^{-3}$ $\mathrm{mm}^{2} / \mathrm{s}$ e $0,4 \pm 0,07 \times 10^{-3} \mathrm{~mm}^{2} / \mathrm{s}$ ), quindi significativamente più basso del valore medio dell'ADC del gruppo di soggetti con 


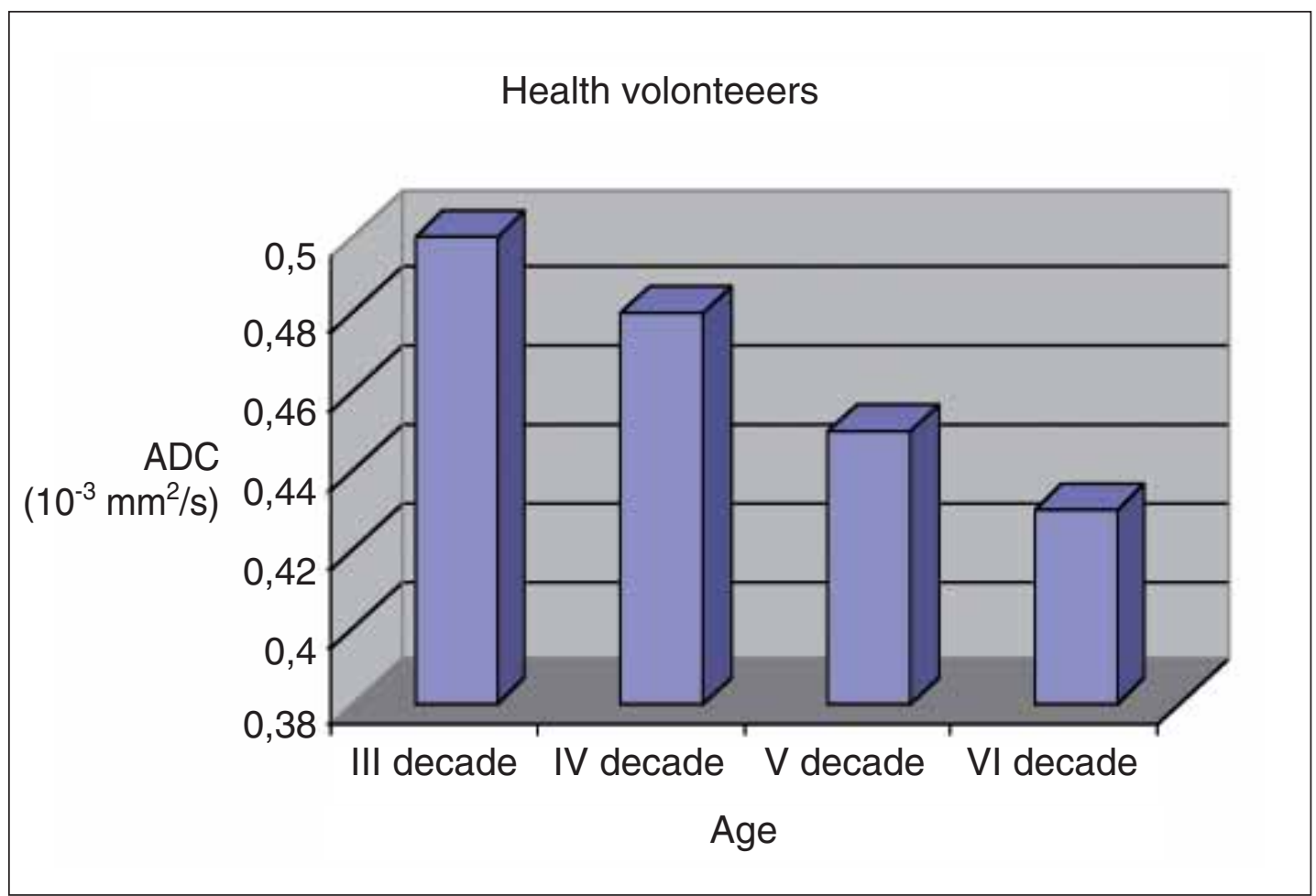

Fig. 6 Relationship between apparent diffusion coefficient (ADC) values and age. Subjects are grouped by age in 10-year intervals. There is a linear increase in ADC value with age.

Fig. 6 Relazione tra valori di coefficiente di diffusione apparente (ADC) ed età. I soggetti sono raggruppati per decadi. Esiste un incremento lineare dei valori di ADC con l'età.

anisotropy produced results overlapping in part with those regarding the calculation of ADC. The mean FA value in this group was 0.29 (value tending towards isotropy), with a range between 0.23 and 0.36 . The lowest values were encountered in premenopausal subjects $(p<0.005)$. The colour maps depicting the degree of anisotropy for all patients in this group showed a gradation of colours regarding the entire vertebral body, which is compatible with a structure characterised by low-grade anisotropy (Fig. 7). The mean ADC value of the osteoporotic patients without vertebral fractures was $0.42 \pm 0.09 \times 10^{-3} \mathrm{~mm}^{2} / \mathrm{s}$ (range between $0.44 \times 0.09 \times 10^{-}$ ${ }^{3} \mathrm{~mm}^{2} / \mathrm{sec}$ and $\left.0.40 \times 0.07 \times 10^{-3} \mathrm{~mm}^{2} / \mathrm{s}\right)$, therefore significantly lower than the mean ADC value of the group of subjects with T score $-1(p<0.001)$. This value was essentially identical to that obtained in osteoporotic patients with vertebral fracture. In some cases of osteoporotic patients, ADC values overlapped with those of patients with a normal $\mathrm{T}$ score but who were also of postmenopausal age (Fig. 8). Table 2 compares mean ADC values and FA obtained in the different groups of patients who underwent diffusion imaging. The mean FA in subjects with $\mathrm{T}$ score $\leq-2.5$ was 0.5 (value tending towards anisotropy), with a range between 0.45 and 0.54 , but the significant finding was that the value increased in proportion to the decrease in $\mathrm{T}$ score. In fact, the colour maps derived from the data revealed a gradation of colours with reference to the entire vertebral body, which is compatible with a structure characterised by intermediate aniso-
T-score $\geq-1(p<0,001)$. Tale valore è risultato invece sostanzialmente sovrapponibile a quello ottenuto nei pazienti osteoporotici con frattura vertebrale. In alcuni casi di pazienti osteoporotici si è verificata una sovrapposizione dei valori di ADC con quelli di pazienti con normale T-score ma anch'essi in età postmenopausale (Fig. 8). La Tabella 2 mette a confronto $i$ valori medi dell'ADC e della anisotropia frazionata (FA) ottenuti nei diversi gruppi di pazienti sottoposti ad imaging di diffusione. Il calcolo della FA nei soggetti con T-score $\leq-2,5$ ha mostrato un valore medio di 0,5 (valore tendente all'anisotropia) con range tra 0,45 e 0,54, ma il dato importante è che tale valore aumentava proporzionalmente alla diminuzione del T-score. Le successive mappe colorimetriche elaborate hanno infatti mostrato una gradazione di colori relativa all'intero corpo vertebrale compatibile con una struttura caratterizzata da un'anisotropia di grado medio con prevalenza dei moti diffusivi dell'acqua di tipo superiore-inferiore, espressa dalla dominanza del colore blu (prevalentemente nelle porzioni centrali del corpo vertebrale) (Figg. 9, 10).

\section{Discussione}

Allo stato attuale non esistono indagini in grado di valutare lo stato di indebolimento dell'osso oltre il quale forze nor- 

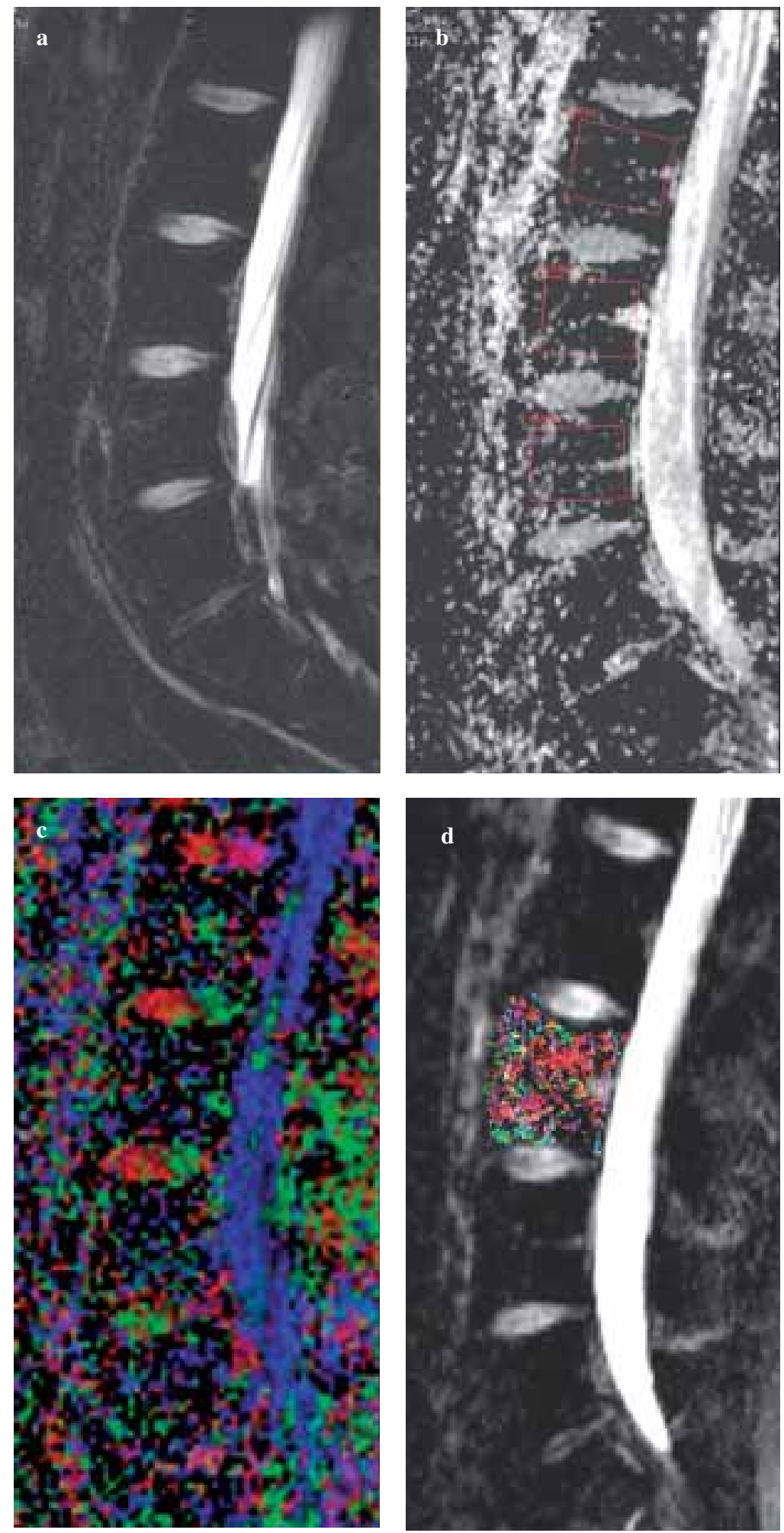

Fig. 7a-d Healthy 39-year-old man. Diffusion-weighted imaging (DWI) (a) and apparent diffusion coefficient (ADC) map (b) with the regions of interest (ROIs) allowing quantitative analysis of the degree of both mean diffusivity and anisotropy within vertebral bodies of L2, L3 and L4. The corresponding colour map (c) of diffusivity direction [directionally encoded colour (DEC)] and the tractography (d) of fibres corresponding to the diffusion of water molecules confirm reduced diffusivity and absence of a preferential pathway of diffusion visually shown by the lack of a dominant colour.

Fig. 7a-d Volontario sano maschio di 39 anni. Immagine pesata in diffusione (a) e rispettiva mappa di ADC (b) con il posizionamento delle ROI per l'analisi quantitativa del grado di diffusività media e di anisotropia all'interno dei somi vertebrali L2, L3 ed L4. La corrispondente mappa colorimetrica (c) di codifica della direzione della diffusività (Directionlly-Encoded Color, DEC) e la elaborazione trattografica (d) delle fibre corrispondenti al moto di diffusione delle molecole di acqua hanno confermato la ridotta diffusività e l'assenza di una direzione preferenziale di diffusione dimostrate visivamente dalla mancanza di un colore dominante. 


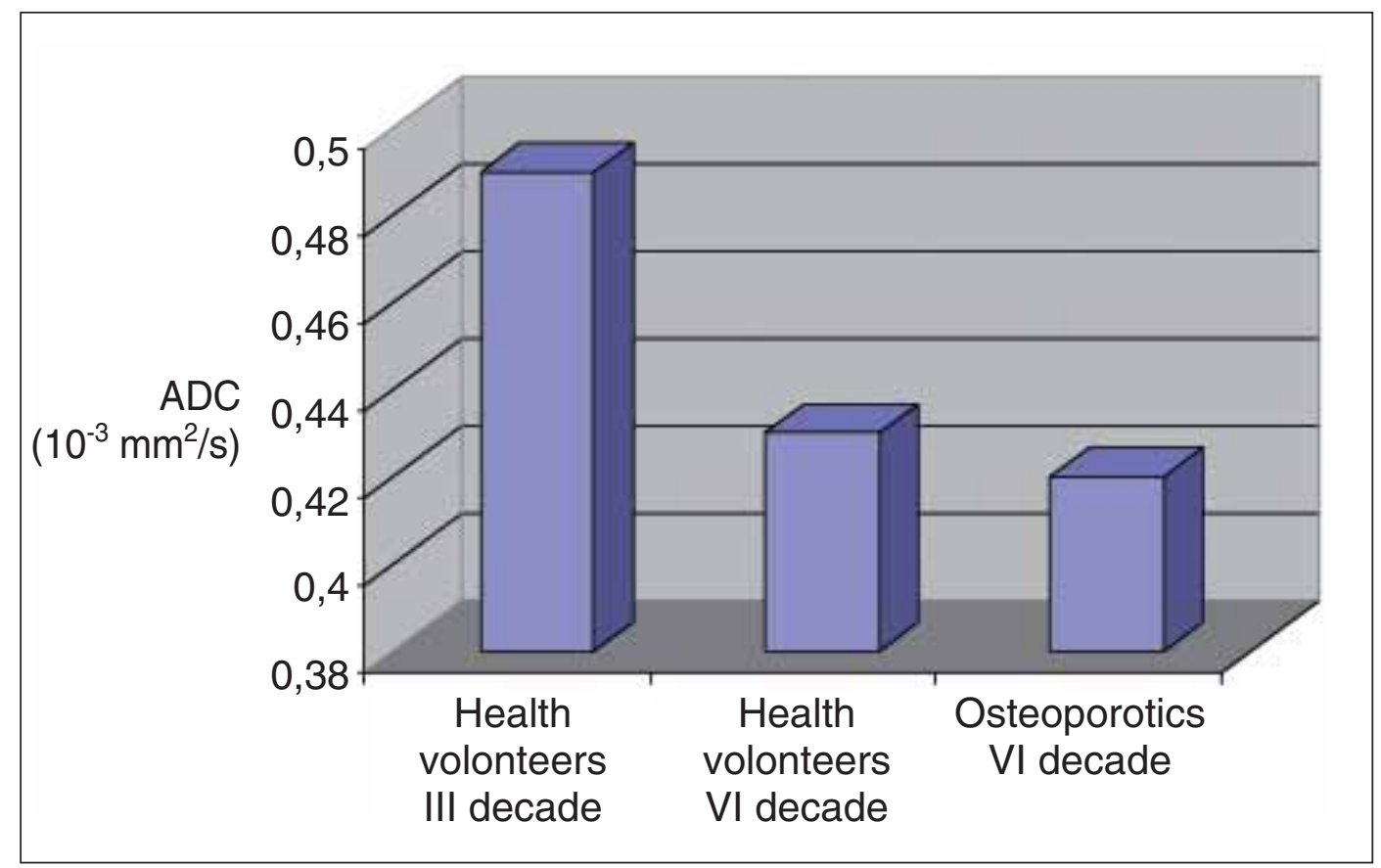

Fig. 8 Comparison between apparent diffusion coefficient (ADC) values in young healthy subjects (30-40 years old) and healthy osteoporotic subjects in postmenopausal age. Young healthy subjects show a medium ADC value higher than subjects of postmenopausal age regardless of their T score.

Fig. 8 Confronto tra valori medi di ADC in soggetti sani di età giovane (III decade) e soggetti sani ed osteoporotici in età post-menopausa. I soggetti sani giovani presentano un valore medio di ADC significativamente più alto rispetto ai soggetti in età post-menopausa, indipendentemente dal valore di T-score di questi ultimi.

Table 2 Mean diffusivity and fractional anisotropy values

\begin{tabular}{lll}
\hline Subject group & Mean diffusivity $\left(\mathrm{ADC}, \mathrm{mm}^{2} / \mathrm{s}\right)$ & Fractional anisotropy $(\mathrm{FA})$ \\
\hline Healthy younger than 50 years & $0.47 \pm 0.08 \times 10^{-3}$ & $0.26 \pm 0.05$ \\
Healthy older than 50 years & $0.45 \pm 0.06 \times 10^{-3}$ & $0.33 \pm 0.04$ \\
Osteoporotic without fracture & $0.43 \pm 0.07 \times 10^{-3}$ & $0.51 \pm 0.05$ \\
Osteoporotic with fracture & $0.39 \pm 0.09 \times 10^{-3}$ & $0.53 \pm 0.05$ \\
$P$ value & $<0.01$ & $<0.05$ \\
\hline
\end{tabular}

Data expressed in terms of mean and standard deviation $A D C$, apparent diffusion coefficient

Tabella 2 Valori di diffusività media e anisotropia frazionaria.

\begin{tabular}{lll}
\hline Parametri & Diffusività media $\left(\mathrm{ADC}, \mathrm{mm}^{2} / \mathrm{s}\right)$ & Anisotropia frazionaria $(\mathrm{FA})$ \\
\hline Sani di età inferiore a 50 anni & $0,47 \pm 0,08 \times 10^{-3}$ & $0,26 \pm 0,05$ \\
Sani di età superiore a 50 anni & $0,45 \pm 0,06 \times 10^{-3}$ & $0,33 \pm 0,04$ \\
Osteoporotici senza frattura & $0,43 \pm 0,07 \times 10^{-3}$ & $0,51 \pm 0,05$ \\
Osteoporotici con frattura & $0,39 \pm 0,09 \times 10^{-3}$ & $0,53 \pm 0,05$ \\
$P$ & $<0,01$ & $<0,05$ \\
\hline
\end{tabular}

Tutti i dati sono espressi in termini di media e deviazione standard $A D C$, coefficiente di diffuzione apparente 

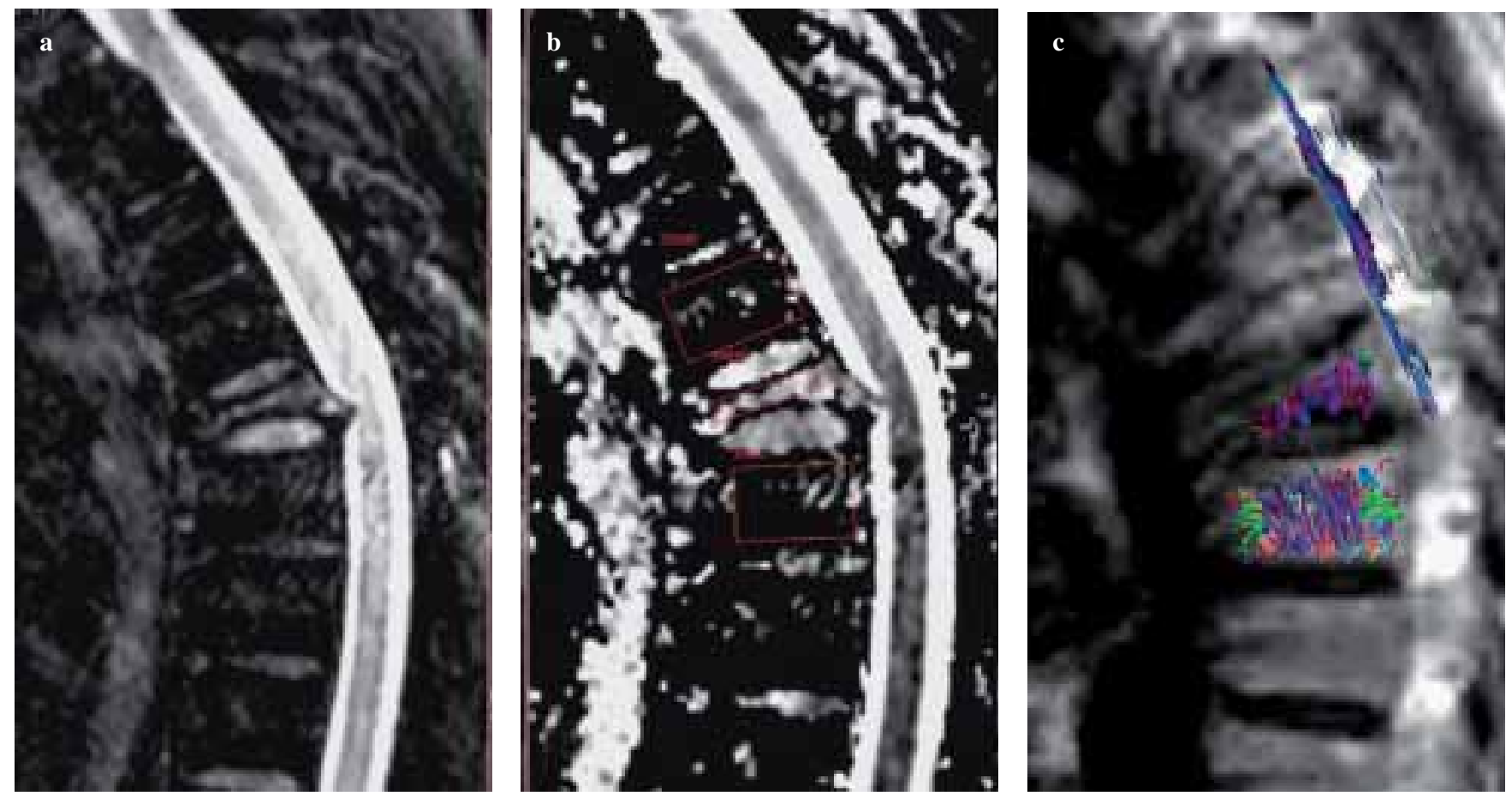

Fig. 9a-c A 68-year-old osteoporotic female patient with a recent fracture of D7. Diffusion-weighted imaging (DWI) (a) and corresponding apparent diffusion coefficient (ADC) map (b). The collapsed vertebral body shows an increase in ADC values demonstrated by an increase in signal intensity. Tractography (c) of the collapsed vertebral body and the underlying vertebral body shows a preferential craniocaudal diffusion direction visually demonstrated by the presence of blue-coloured fibres.

Fig. 9a-c Paziente di sesso femminile di 68 anni, osteoporotica, con frattura vertebrale di $D 7$ recente. Immagine pesata in diffusione (a) e rispettiva mappa di $A D C(\boldsymbol{b})$. A livello del soma crollato è evidente un significativo aumento dei valori di ADC dimostrato visivamente da un aumento dell'intensità di segnale. La successiva elaborazione trattografica (c) effettuata a livello del soma vertebrale crollato e di quello sottostante, ha evidenziato una via preferenziale di diffusione nella direzione superiore-inferiore dimostrata visivamente dalla presenza di fibre direzionate con dominanza di colore blu.

tropy with a prevalence of water diffusion of the superior-inferior type, which is expressed by the dominance of blue in the map (prevalently in the central portions of the vertebral body) (Figs. 9, 10).

\section{Discussion}

There are no examinations capable of assessing either the degree of bone weakening beyond which normally occurring forces may cause vertebral collapse, or the specific level at which the risk is greatest. BMD and the T score are the two main parameters linked to bone weakening [8]. The examination capable of calculating those parameters and therefore the degree of bone strength is DEXA, which nonetheless only assesses the quantity of bone mineral. Quantitative histological studies performed on bone biopsies with regard to the changes in bone with age have shown the progressive, gradual and constant increase in the content of fats in bone marrow [9], with greater evidence found in osteoporotic subjects [10]. Bone marrow is known to consist primarily of saturated, monounsaturated and polyunsaturated fatty acids [11], but it is unknown if (and how) that composition varies in osteoporosis. A very recent study carried out by Yeung et malmente agenti possano causare un evento fratturativo in un corpo vertebrale, né tanto meno il livello specifico dove tale rischio è più alto. La BMD ed il T-score sono i due principali parametri legati alla debolezza dell'osso [8]. L'indagine in grado di calcolare tali parametri e quindi il grado di robustezza dell'osso è la DEXA, la quale valuta unicamente però solo la quantità minerale ossea. Studi istologici quantitativi eseguiti su biopsie ossee relativi alle modificazioni dell'osso legate all'età hanno mostrato il progressivo, graduale e costante aumento del contenuto di lipidi nel midollo osseo [9], con maggiore evidenza nei soggetti osteoporotici [10]. Ė noto che il midollo osseo consiste primariamente di acidi grassi saturi, monoinsaturi e polinsaturi [11], ma non è noto se (o come) tale composizione varia nell'osteporosi. Un recentissimo studio condotto da Yeung et al. [12] con tomografo a risonanza magnetica da 1,5 T, in cui sono stati messi a confronto i risultati della spettroscopia effettuata a livello di L3 di una popolazione di donne in post-menopausa osteoporotiche con lo spettro ottenuto da un fantoccio di olio di mais, ha dimostrato che il contenuto di acidi grassi insaturi nel midollo osseo, calcolato come porzione della frazione lipidica totale $(F F)$, presentava una evidente tendenza al decremento quando si passava da soggetti sani a soggetti osteoporotici di pari età e sesso, e che contestualmente esisteva un aumento degli acidi grassi saturi. 

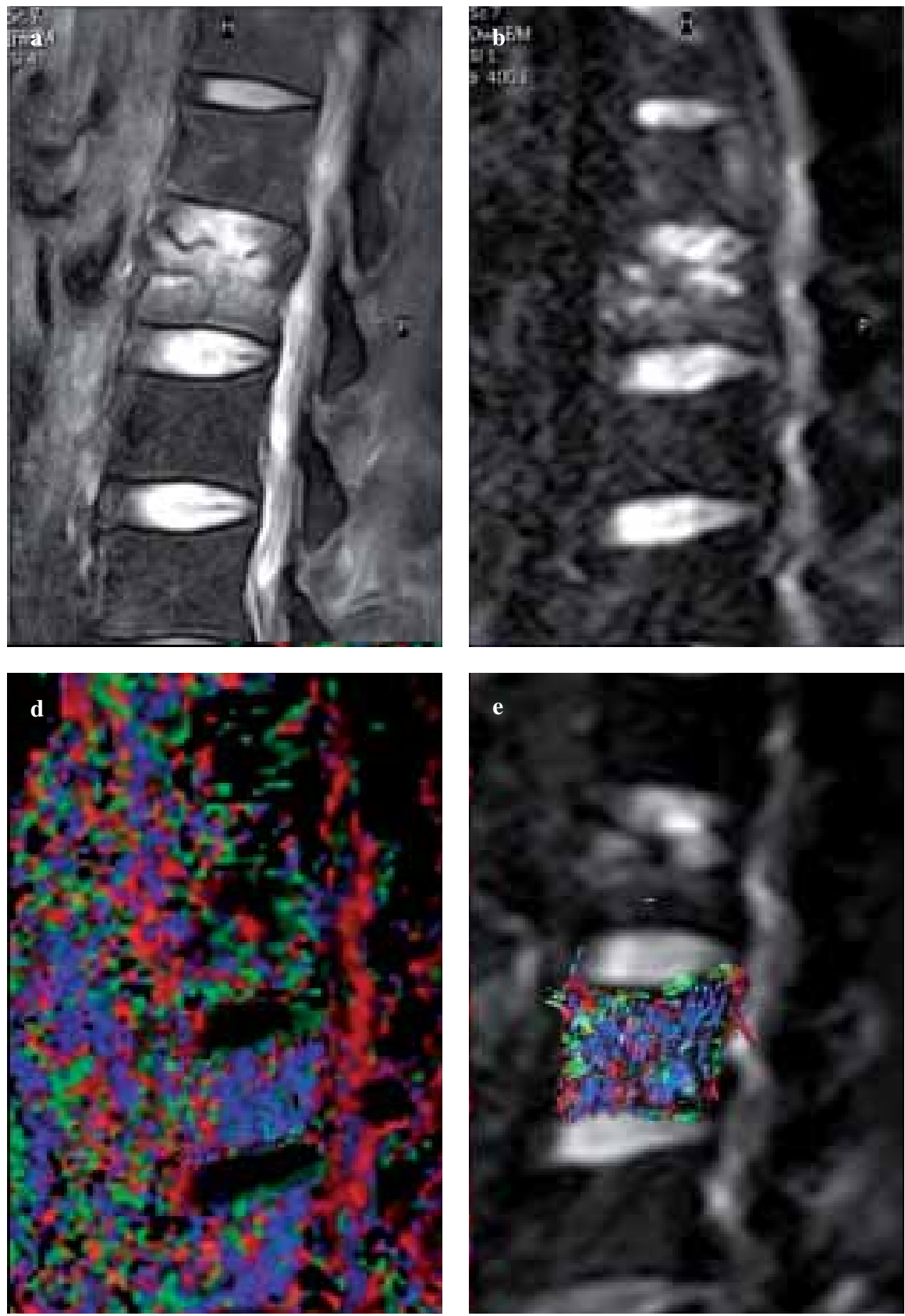

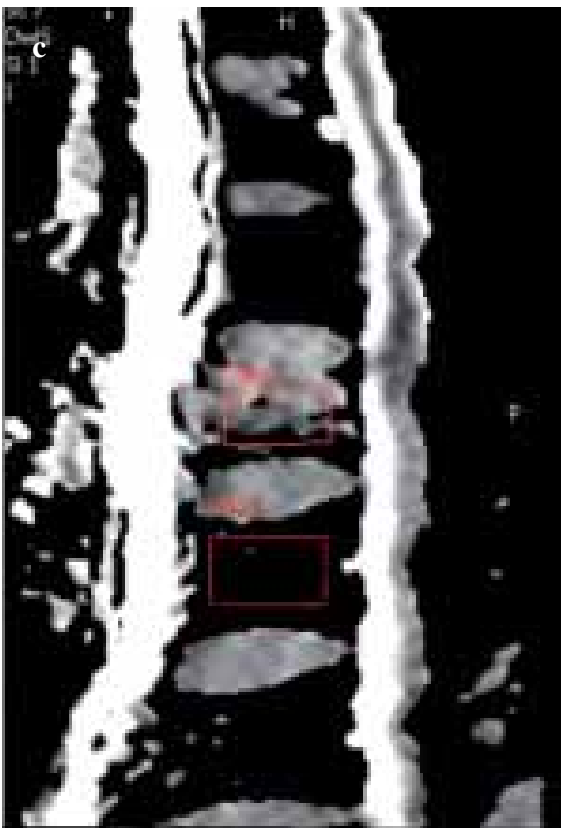

Fig. 10a-e Osteoporotic 65-year-old patient with a recent L1 fracture (a). Diffusion-weighted imaging (DWI) (b) and corresponding fractional anisotropy (FA) map (c) with a region of interest (ROI) within the body of the vertebra below the collapsed one. Prevalence of the blue colour at the L2 level, shown in the corresponding colour map (d) of direction encoding of diffusivity, demonstrates a preferential craniocaudal direction pathway of diffusion of water molecules, confirmed by the tractographic study (e).

Fig. 10a-e Paziente osteoporotica di 65 anni con frattura recente di L1 (a). Immagine pesata in diffusione $(\boldsymbol{b})$ e rispettiva mappa di $F A$ (c) con il posizionamento della ROI all'interno del soma sottostante il corpo vertebrale crollato. La prevalenza del colore blu a livello di L2, evidente nella corrispondente mappa colorimetrica (d) di codifica della direzione della diffusività, ha infatti dimostrato una via preferenziale di diffusione delle molecole di acqua nella direzione superiore-inferiore, confermata dalla successiva elaborazione trattografica $(\boldsymbol{e})$. al. [12] with a 1.5-T MR scanner compared the results of spectroscopy performed at the level of L3 on a population of postmenopausal osteoporotic women, with the spectrum obtained from a phantom of maize oil. The findings demonstrated that the content of unsaturated fatty acids in bone marrow, calculated as a portion of the total FF, was clearly lower in osteoporotic subjects than in healthy subjects of the same age and gender, whereas the level of saturated fats was higher in the first group. The data obtained in our spectroscopic study fully confirm the findings of Yeung, and even enable improved separation of the various molecular components of the spectrum and increased accuracy of assessing the individual fat peaks. This supports the fact that the techniques that benefit the most from the use of a 3-T magnetic
I dati ottenuti dal nostro studio di spettroscopia confermano pienamente i risultati riportati da Yeung, ed anzi consentono di separare meglio le varie componenti molecolari dello spettro e di aumentare l'accuratezza nella valutazione dei singoli picchi lipidici. Questo a riprova del fatto che a risentire maggiormente in maniera positiva dell'utilizzo di un campo magnetico a $3 T$ dovrebbe essere proprio l'imaging spettroscopico $\left({ }^{1} \mathrm{H}\right.$-MRSI), la valutazione della diffusione protonica (DWI) ed il calcolo del tensore di diffusione (DTI).

La relazione esistente tra frazione di lipidi midollari e debolezza ossea può essere spiegata da diversi fattori. Primo, la rarefazione ed assottigliamento delle trabecole dell'osso spugnoso è comunemente riportata come la principale causa di debolezza ossea nell'osteporosi. L'assotti- 
field are precisely spectroscopy imaging $\left({ }^{1} \mathrm{H}-\mathrm{MRS}\right)$, diffusion-weighted imaging (DWI) and DTI.

The relationship between the fraction of bone marrow fats and bone weakening can be explained by a variety of factors. Firstly, trabecular thinning, which causes an increase in the intertrabecular spaces, is often given as the main cause of bone weakening in osteoporosis. A number of authors have suggested the presence of a compensatory mechanism that fills those spaces with yellow marrow $[9,13,14]$. In particular, Dunnill et al. [9] suggested that with increasing age, the increase in bone marrow fats is even more marked than the reduction in red marrow, probably because the yellow marrow tends not only to replace the loss of bone but also the loss of red marrow. A greater quantity of fat cells is therefore required to replace the loss of cancellous bone and the spaces formerly occupied by red marrow. Secondly, increased adipogenesis competes with osteogenesis, thus reducing the population of osteoblasts. Indeed, there is a reciprocal relationship between fat cells and osteoblasts, with the result of a loss of bone mass. This theory has found support in animal studies [15]. Thirdly, and most importantly, bone marrow fats can directly influence the quality of bone trabeculae. In fact, it is thought that the quality of bone marrow plays an important role in vertebral mechanical resistance and that an increase in fats can negatively influence this. Young bone marrow that fills the intratrabecular spaces functions as a shock absorber and acts as a biomechanical support structure for the cancellous bone. Yellow marrow, due to its high fat content, is a weaker means of biomechanical support than is red marrow [16]. Our data show that postmenopausal patients with a $\mathrm{T}$ score $\leq-2.5$ reveal a consistent increase in FF when compared with healthy postmenopausal subjects.

FF values, however, were not significantly different from those of patients with a normal $\mathrm{T}$ score of the same gender and age. This finding was also confirmed by the ADC calculation performed in the same group of subjects. This may mean that both the spectroscopic analysis and the DWI can identify early changes in the microarchitecture of the cancellous bone of the vertebral body, even when the T score is normal, and therefore before the phenomenon can be detected with DEXA.

Currently available imaging techniques such as DEXA assess the final structural result of osteoporosis, but they fail to provide information regarding the physiopathology of the disease. Our study reveals an ADC value in postmenopausal patients with a T score $\leq-2.5$ significantly lower $(p<0.01)$ than the premenopausal group, a finding that is in agreement with the latest studies [17]. ADC values reported by Zhou et al. [18] were significantly different, but they were not used for comparison because the $\mathrm{b}$ value used in that study was below $250 \mathrm{~mm}^{2} / \mathrm{s}$.

The lower diffusivity of water in the vertebral bodies of older patients compared with younger patients may indicate changes in the composition of bone marrow correlated with age. Quantitative histological [9] and spectroscopic [19] studies have shown that the quantity of fat present in bone increases with age. These findings are in agreement with the data in our study and suggest that the increase in marrow fat gliamento trabecolare risulta in un aumento degli spazi intertrabecolari. È stato suggerito da diversi autori che esiste un fenomeno compensatorio di riempimento di tali spazi con midollo giallo [9, 13, 14]. In particolare, Dunnill [9] ha suggerito che, con l'aumentare dell'età, l'incremento dei lipidi midollari è ancora più marcato della riduzione del midollo rosso, presumibilmente perché il midollo giallo va a rimpiazzare tanto il midollo rosso quanto la perdita di osso. Una quantità superiore di cellule adipose è pertanto necessaria per rimpiazzare la perdita di osso trabecolare e riempire gli spazi prima occupati dal midollo rosso. Secondo, l'aumentata adipogenesi compete con l'osteogenesi riducendo la popolazione di osteoblasti. Infatti, esiste una relazione reciproca tra adipociti ed osteoblasti. Ne risulta una perdita di massa ossea. Questa teoria è supportata da studi in animali [15]. Terzo e più importante fattore, i lipidi midollari possono direttamente influenzare la qualità delle trabecole ossee. Si ritiene, infatti, che la qualità del midollo osseo sia un importante fattore determinante la resistenza meccanica vertebrale e che l'incremento dei lipidi possa influenzarla negativamente. Il midollo osseo giovane che riempie gli spazi inter-trabecolari funziona come ammortizzatore di carico e agisce come struttura di supporto biomeccanico per l'osso spongioso. Il midollo giallo, per il suo alto contenuto di adipociti, è un mezzo di supporto biomeccanico più debole rispetto al midollo rosso [16]. I nostri dati hanno mostrato che pazienti in età postmenopausale con $T$ score $\leq-2,5$ presentavano un consistente aumento della frazione lipidica $(F F)$ se comparati a soggetti sani di pari sesso in età pre-menopausa.

I valori di FF non sono stati invece significativamente diversi da quelli di pazienti con $T$-score normale, ma di pari sesso ed età. Tale dato è stato confermato anche dal calcolo dell'ADC effettuato negli stessi gruppi di soggetti e potrebbe significare che sia l'analisi spettroscopica che l'imaging di diffusione possono riflettere cambiamenti precoci nella microarchitettura della spongiosa ossea del corpo vertebrale quando ancora il T-score risulta normale e quindi prima che tale fenomeno sia rilevabile con la DEXA.

Le attuali tecniche di imaging come la DEXA valutano il risultato strutturale finale dell'osteoporosi ma non danno infatti informazioni circa la fisiopatologia. Questo studio ha evidenziato, nei soggetti in età post-menopausa con T-score£-2,5, un valore di $A D C$ significativamente più basso $(p<0,01)$ rispetto al gruppo di soggetti di età pre-menopausa, in accordo con i più recenti studi presenti in letteratura [17]. I valori di ADC riportati da Zhou et al. [18] sono risultati significativamente diversi, ma non sono stati confrontati perché in tale studio sono stati utilizzati valori di b inferiori a $250 \mathrm{~mm}^{2} / \mathrm{s}$.

La minore diffusività dell'acqua nei corpi vertebrali dei soggetti più anziani comparata con quella dei soggetti più giovani potrebbe essere un indicatore delle alterazioni nella composizione del midollo osseo correlate all'età. Studi istologici quantitativi [9] e spettroscopici [19] hanno mostrato che $i$ valori dei lipidi nell'osso aumentano con l'età. Questi risultati sono in accordo con i dati del nostro studio, e suggeriscono che l'aumento del grasso midollare associato con l'osteoporosi potrebbe rendere ragione dei valori dell'ADC significativamente più bassi. L'incremento di lipidi all'inter- 
associated with osteoporosis may explain the significantly lower ADC values. The increase in fats within the trabeculae of vertebral bodies may reduce extracellular diffusion and lead to a reduction in ADC values.

With regard to data provided by DTI, the analysis of ADC and FA proved to be the most reliable. This confirms the potential of DWI in assessing early changes in bone metabolism. A more complex matter, however, is interpretation of the colour maps that codify the main direction of diffusivity; for these to be reliable, further studies on the structural variations of the cancellous bone of osteoporotic vertebral bodies need to be performed.

Even though further studies are required, our data demonstrates that 3-T MR has an important role to play in the development of our understanding of vertebral osteoporosis. no delle trabecole ossee dei corpi vertebrali potrebbe ridurre la diffusione extracellulare e portare ad una riduzione dei valori dell'ADC.

Per quanto riguarda i dati forniti dal tensore di diffusione è soprattutto l'analisi della ADC e della FA a risultare attendibile; tale elemento conferma le potenzialità dell'imaging di diffusione nella valutazione precoce dei cambiamenti del metabolismo osseo. Ben più complessa rimane l'interpretazione delle mappe colorimetriche di codifica della direzione principale della diffusività alle quali devono, per risultare attendibili, essere abbinati ulteriori studi sulle variazioni strutturali della spongiosa nel corpo vertebrale osteoporotico.

Sebbene ulteriori studi siano necessari, i nostri dati indicano che la RM 3 T rappresenta un importante strumento per l'avanzamento delle conoscenze sull'osteoporosi vertebrale.

\section{References/Bibliografia}

1. Lindsay R, Silverman $\mathrm{Sl}$, Cooper $\mathrm{C}$ et al (2001) Risk of new vertebral fracture in the year following a fracture. Jama 285:320-323

2. Wasnich U (1996) Vertebral fracture epidemiology. Bone 18:s179-s183

3. Basser P, Pajevic S, Pierpaoli C et al (2000) In vivo fiber tractography using DT-MRI data. Magn Reson Med 44:625-632

4. Basser PJ, Mattiello J, LeBihan D (1996) MR imaging of fiber tract direction and diffusion in anisotropic tissues. In: Proceedings of the 4th Annual Meeting of ISMRM, New York, p 288

5. Jones D, Williams S, Horsfield M (1997) Full representation of white matter fiber direction on one map via diffusion tensor analysis. In: Proceedings of the 5th Annual Meeting of ISMRM, Vancouver, Canada, p 1743

6. Mori S, Crain BJ, Chacko VP, van Zijl PCM (1999). Three dimensional tracking of axonal projections in the brain by magnetic resonance imaging. Ann Neurol 45:265-269

7. Guillen MD, Ruiz A (2003) Rapid simultaneous determination by proton NMR of unsaturation and composition of acryl groups in vegetable oils. Eur J Lipid Sci Technol 105:688-696
8. Osteoporosis prevention, diagnosis and therapy (2000) NIH Consens Statement, March 27-29, 17:1-45

9. Dunnill MS, Anderson JA, Whitehead R (1967) Quantitative histological studies on age changes in bone. J Pathol Bacteriol 94:275-291

10. Verna S, Rajaratnam JH, Denton J et al (2002) Adipocytic proportion of bone marrow is inversely related to bone formation in osteoporosis. J Clin Pathol 55:693-698

11. Gunstone FD, Harwood JL, Padley FB (1994) The lipid handbook, 2nd ed. Chapman and Hall, London

12. Yeung DKW, Griffith JF, Antonio GE et al (2005) Osteoporosis is associated with increased marrow fat content and decreased marrow fat unsaturation: a proton MR Spectroscopy study. J Magn Reson Imaging 22:279-285

13. Lang P, Steiger P, Faulkner K et al (1991) Osteoporosis: current techniques and recent developments in quantitative bone densitometry. Radiol Clin North Am 29:49-76

14. Dooms GC, Fisher MR, Hricak H et al (1985) Bone marrow imaging: magnetic resonance studies related to age and sex. Radiology 155:429-432
15. Beresford JN, Bennett JH, Delvin C et al (1992) Evidence for an inverse relationship between the differentiation of adipocytic and osteogenic cells in rat marrow stromal cell cultures. J Cell Sci 102:341-351

16. Kazarian L, Graves GA (1977) Compressive strength characteristics of the human vertebral column. Spine 2:1-13

17. Yeung D, Wong S, Griffith JF et al (2004) Bone marrow diffusion in osteoporosis: evaluation with quantitative MR Diffusion imaging. J Magn Reson Imaging 19:222-228

18. Zhou XJ, Leeds NE, McKinnon GC et al (2002) Characterization of benign and metastatic vertebral compressure fractures with quantitative diffusion MR imaging. AJNR Am J Neuroradiol 23:165-170

19. Schellinger D, Lin CS, Fertlikh D et al (2000) Normal lumbar vertebrae: anatomic, age and sex variance in subjects at proton MR spectroscopyinitial experience. Radiology 215:910-916 